\title{
Rhizobacterial inoculation in combination with mineral fertilizer improves maize growth and yield in poor ferruginous soil in central Benin
}

\author{
Olaréwadjou Amogou ${ }^{1}$, Agossou P. Noumavo ${ }^{1,2}$, Nadège A. Agbodjato ${ }^{1}$, Haziz Sina ${ }^{1}$, \\ Gustave Dagbénonbakin ${ }^{3}$, Marcel Y. AdoKo ${ }^{1}$, VAlÈre K. SAlaKo ${ }^{4}$, Romain Glèlè KaKaİ ${ }^{4}$, \\ AdOLPHE AdJANOHOUN ${ }^{3}$, LAMINE BABA-MOUSSA ${ }^{1 *}$ \\ ${ }^{1}$ Laboratoire de Biologie et de Typage Moleculaire en Microbiologie, Departement de Biochimie et de Biologie Cellulaire, \\ Faculté des Sciences et Techniques, Université d’Abomey-Calavi, Cotonou, Benin \\ ${ }^{2}$ Laboratoire de Microbiologie et des Technologies Alimentaires, Département de Biologie Végétale, \\ Faculté des Sciences et Techniques, Université d'Abomey-Calavi, Cotonou, Bénin \\ ${ }^{3}$ Institut National des Recherches Agricoles du Bénin, Cotonou, Bénin \\ ${ }^{4}$ Laboratoire de Biomathématique et d'Estimation Forestière, Faculty of Agronomic Sciences, \\ University of Abomey-Calavi, Cotonou, Bénin
}

\begin{abstract}
The use of biotechnological approaches to increase soil fertility and productivity allows to obtain sustainable agriculture with lesser use of chemical fertilizers. The present study aimed to determine whether the inoculation of Bacillus panthothenicus, Bacillus thuringiensis, Pseudomonas putida, Pseudomonas syringae, or Serratia marcescens combined with reduced doses of NPK (nitrogen, phosphorus, potassium) fertilizer can improve the growth and yield of maize on poor ferruginous soils under field conditions in central Benin. For this purpose, maize seeds of the EVDT 97 STR C1 variety were inoculated with $10 \mathrm{ml}$ suspension of five plant growth-promoting rhizobacteria (PGPR) strains, and the plots were fertilized at seeding with the recommended doses $(0,25,50,100 \%)$ of $200 \mathrm{~kg} / \mathrm{ha}$ of NPK and $100 \mathrm{~kg}$ of urea for corn cultivation. The study was conducted in a completely randomized design with 3 replicates. The results showed that except for $P$. syringae, which induced the highest fresh aerial biomass (94.51\%) and dry aerial biomass (63.63\%), all other parameters were positively improved with inoculation associated with reduced doses of NPK + urea. The best height, leaf area, fresh underground biomass, and grain yield were recorded in response to the application of $P$. syringae $+50 \% \mathrm{NPK}+$ urea, with an increase of 26.82 , $32.23,107.57$, and $30.64 \%$, respectively, compared to those of the control. The inoculation of seeds with $P$. syringae $+50 \% \mathrm{NPK}+$ urea can be considered to be an environmentally sustainable strategy for maize cultivation.
\end{abstract}

Key words: PGPR, biofertilizer, poor ferruginous soil, Zea mays L., Benin

\section{Introduction}

Maize is an important crop in Africa and the rest of the world. It is one of the three main nutritious crops that serves as a staple diet for more than half of the world's population (FAO, 2009; Macauley, 2015). In Benin, maize is grown as a strategic crop in terms of food security and economic profitability, and consequently, it is regarded by the government of Benin as the main crop whose production needs to be intensified in order to achieve food self-sufficiency (Toléba-Seïdou et al., 2015;
APRM, 2017). At the national level, maize production has increased from $864698 \mathrm{t}$ in 2005 to $1600000 \mathrm{t}$ in 2018 (Gogan et al., 2018), albeit with low yields per hectare $(<3 \mathrm{t} / \mathrm{ha})$, which is below the potential yield of the plant ( 3 to $6 \mathrm{t} / \mathrm{ha}$ ) despite the favorable ecology for its production in all agro-ecological zones (Azontondé et al., 2010; Adjanohoun et al., 2012; Sikirou et al., 2019). One of the main factors that affects soil fertility in modern agriculture is abiotic stress caused by climate change, soil salinity, and soil degradation, which has a severe 
negative effect on food availability (Maheshwari, 2012; Goyal and Manoharachary, 2014). In Benin, the phenomenon of soil degradation is increasing, particularly in the central and northern regions dominated by ferruginous soils (Amadji and Migan 2001). This situation contributes to the depletion of soil organic matter and nutrients essential for plant development. The resulting decline in soil fertility is a major concern for both farmers and allied services, which has ultimately led to a full-fledged project in the National Agricultural Research Programme (NARP) adopted by the Government in the Council of Ministers on June 13, 2018 (INRAB, 2018). Current agricultural systems implemented to ensure better productivity depend heavily on the continuous application of mineral fertilizers, mainly nitrogen $(\mathrm{N})$, phosphorus $(\mathrm{P})$, and potassium $(\mathrm{K})$, which contribute to the deterioration of soil biological fertility due to the loss of microbial population beneficial for plants (Gyaneshwar et al., 2002; Mahanty et al., 2017). The presence and high activity of microorganisms is often considered as an indicator of good soil fertility (Patra et al., 2008; De Souza et al., 2015). To meet the abovementioned challenges, the development of different production techniques based on the importance of different nutrient sources and the potential of soil microorganisms, especially plant growth-promoting rhizobacteria (PGPR), has become an urgent necessity. Indeed, a microbial inoculation technology using PGPRs has been proposed to improve crop production yields in several regions of the world (Rashid et al., 2016; Dicko et al., 2018; Zahir et al., 2018). PGPRs influence plant health and productivity through various mechanisms. The direct mechanism involves soil improvement and the production of substances needed for plant growth, which enhances fertility by mobilizing soil minerals. These improvements include the supply of growth regulators and essential minerals such as $\mathrm{N}$ and $\mathrm{P}$. The indirect mechanism involves production of biocontrol agents that inactivate or kill pathogens, thereby providing a healthy growth environment for plants. Moreover, bacteria can also indirectly improve plant growth by suppressing pathogens and increasing plant innate immunity against pathogens (Tabassum et al., 2017; Saikia et al., 2018; Naik et al., 2019). Currently, PGPRs are the most widely used tools because of their effectiveness and relatively low cost in managing and improving soil productivity in sustainable harmony with populations of beneficial and pathogenic soil microorga- nisms and human health (Batool et al., 2014; GontiaMishra et al., 2016; Ahmad et al., 2019 ). The present study assessed the effect of inoculation of PGPR isolated from the maize rhizosphere in central and northern Benin and the intake of different doses of NPK-Urea on maize productivity on poor ferruginous soil in central Benin with a view to their valorization in the production system for ecological and sustainable agriculture.

\section{Materials and methods}

\section{Characteristics of rhizobacteria strains}

The rhizobactéries strains Bacillus panthothenicus, Bacillus thuringiensis, Pseudomonas putida, Pseudomonas syringae, and Serratia marcescens used in this study were selected on the basis of their ability to promote greenhouse maize growth parameters (Amogou et al., 2019). The strains were isolated and characterized from the maize rhizosphere of different agro-ecological zones of central and northern Benin by Agbodjato et al. (2015) and stored at $-86^{\circ} \mathrm{C}$ in Muller-Hinton broth with glycerol (10\%) at the Laboratory of Biology and Molecular Typing in Microbiology, the University of Abomey Calavi, Republic of Benin.

\section{Preparation of the inoculum}

After culturing the strains of Pseudomonas on Middle King B (Guiraud and Galzy, 1994) and those of BacilIus and Serratia on Nutritive Agar (Wahyudi et al., 2011; Aparna and Sarada, 2012), the corresponding inocula of the different PGPRs were obtained by growing in nutrient culture (Mueller Hinton Broth) for $24 \mathrm{~h}$ at $30^{\circ} \mathrm{C}$. Bacterial culture concentrations were adjusted to approximately $1 \times 10^{8} \mathrm{CFU} / \mathrm{ml}$ (DO 0.45 to $610 \mathrm{~nm}$ ) with a spectrophotometer using the method of Govindappa et al. (2011).

\section{Description of the study site}

The trial was conducted in Miniffi in central Benin in the municipality of Dassa-Zoumè (Fig. 1). It is home to depleted tropical ferruginous soil with low water supply. The location is characterized by a Sudano-Guinean tropical climate with an annual rainfall and large temperature variations with an annual average of around $28^{\circ} \mathrm{C}$; the average annual rainfall is $1481 \mathrm{~mm}$, and the average annual potential evapotranspiration is $1648 \mathrm{~mm}$ (Balogoun, 2012). 


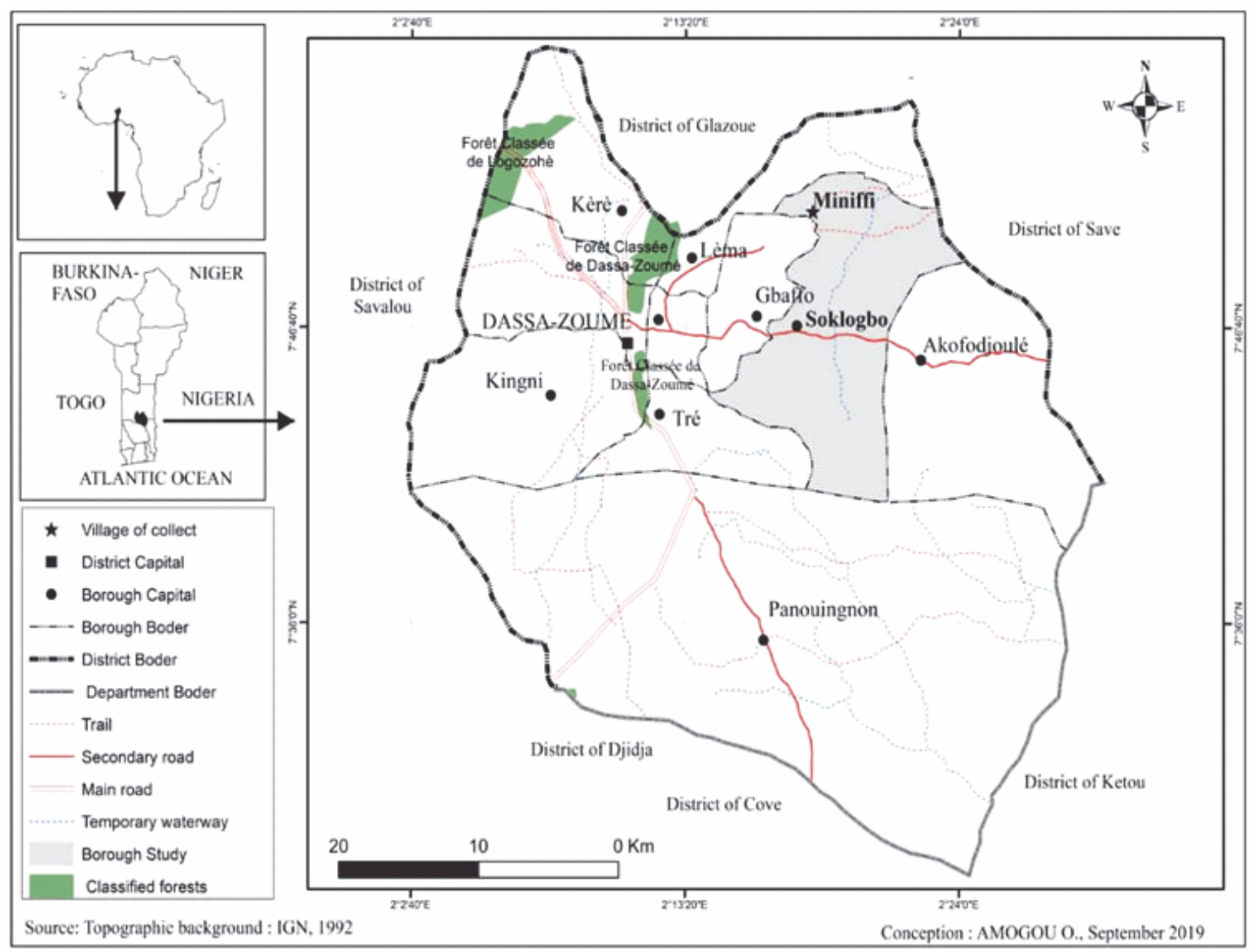

Fig. 1. Map of the study area showing the experimental site (Amogou, 2019)

\section{Experimental design}

The experiment was conducted in a split-split plotbased randomized complete block design with three replications. The large plot factor was the fertilizer dose and the small plot factor was the concentration of PGPR. A total of 22 treatments were compared, with three repetitions each. The plots were divided into three large blocks that represented the repetitions. Each block was divided into four large parcels, three of which had 7 small plots and the fourth had only one small plot; seeds were randomly sown on each block under the following conditions: without inoculation, with inoculation, and with increasing doses of NPK mineral fertilizer input. Table 1 provides details of the factors and treatments.

\section{Sowing, inoculation of corn seeds, and maintenance of plots}

The maize variety EVDT 97 STR C 1 provided by the National Institute of Agricultural Research in Benin was used. This is an early 90 -day variety, with a potential yield of grain ranging from 4 to $5 \mathrm{t}$ /ha in a pleasant environment. The seeds of this corn are white and toothed, and the texture is mid-farinaceous and mid-vitreous. The EVDT 97 STR C1 variety has a good resistance to American rust, striation, Helminthosporium species, Curvularia species, and drought (Yallou et al., 2010). Two seeds of each treatment were sown at the depth of $5 \mathrm{~cm}$. The seeds were inoculated with $10 \mathrm{ml}$ of bacterial suspension according to each treatment, and the opening was immediately closed. Two weeding towers were carried out 12 days after sowing (DAS) and 42 DAS for the maintenance of the different plots.

\section{Data collection}

The height and diameter at the collar of 12 plants were measured every 15 days by using a tape meter and a sliding foot scale after thinning of the plants up to 60 DAS.

In addition, the leaf surface of the plants was assessed 60 DAS according to the method described by Ruget et al. (1996). The number of feet of corn was counted by 
Table 1. Evaluation of doses of NPK fertilizer $(0,25,50$, and $100 \%$ with no PGPRs) and PGPRs (without PGPR, B. thu., B. pan., P. put., P. syr., and S. mar.)

\begin{tabular}{|c|c|c|}
\hline $\begin{array}{l}\text { Recommended dose } \\
\text { NPK-urea [\%] }\end{array}$ & PGPR & Designation \\
\hline \multirow{7}{*}{0} & control (no bacteria, no mineral fertilizers) & without PGPR \\
\hline & Bacillus panthothenicus & B. pan. \\
\hline & Bacillus thuringiensis & B. thu. \\
\hline & $\begin{array}{l}\text { Bacillus thuringiensis }+ \text { Pseudomonas. putida } \\
+ \text { Serratia marcescens }\end{array}$ & B. thu., P. put., S. mar. \\
\hline & Pseudomonas putida & P. put. \\
\hline & Pseudomonas syringae & P. syr. \\
\hline & Serratia marcescens & S. mar. \\
\hline \multirow{7}{*}{25} & control (1/4 dose of NPK-urea) & without PGPR + 25\% NPK + urea \\
\hline & Bacillus panthothenicus & B. pan. $+25 \% \mathrm{NPK}+$ urea \\
\hline & Bacillus thuringiensis & B. thu. $+25 \% \mathrm{NPK}+$ urea \\
\hline & $\begin{array}{l}\text { Bacillus thuringiensis }+ \text { Pseudomonas. putida } \\
+ \text { Serratia marcescens }\end{array}$ & B. thu., P. put., S. mar. + 25\% NPK + urea \\
\hline & Pseudomonas putida & P. put. $+25 \% \mathrm{NPK}+$ urea \\
\hline & Pseudomonas syringae & P. syr. $+25 \% \mathrm{NPK}+$ urea \\
\hline & Serratia marcescens & S. mar. $+25 \% \mathrm{NPK}+$ urea \\
\hline \multirow{7}{*}{50} & control (half dose of NPK-urea) & without PGPR + 50\% NPK + urea \\
\hline & Bacillus panthothenicus & B. pan. $+50 \% \mathrm{NPK}+$ urea \\
\hline & Bacillus thuringiensis & B. thu. $+50 \% \mathrm{NPK}+$ urea \\
\hline & $\begin{array}{l}\text { Bacillus thuringiensis }+ \text { Pseudomonas. putida } \\
+ \text { Serratia marcescens }\end{array}$ & B. thu., P. put., S. mar. + 50\% NPK + urea \\
\hline & Pseudomonas putida & P. put. $+50 \% \mathrm{NPK}+$ urea \\
\hline & Pseudomonas syringae & P. syr. $+50 \% \mathrm{NPK}+$ urea \\
\hline & Serratia marcescens & S. $m a r .+50 \% \mathrm{NPK}+$ urea \\
\hline 100 & control (full dose of NPK-urea recommended) & without PGPR +100\% NPK + urea \\
\hline
\end{tabular}

an elemental plot following perfect drying of the spaths of the ears, and 12 plants located on the three central lines were removed to evaluate yield parameters. For this purpose, the ears of the plants were harvested, and the fresh aerial parts and underground biomass were separated and weighed. The dry weight of the biomass was measured in the laboratory, after drying in a stove at $65^{\circ} \mathrm{C}$ for at least $72 \mathrm{~h}$. After ginning, the cob stalks of the 12 previously plucked corn plants were weighed with a scale (highland HCB 302, max: $3001 \mathrm{~g}$ ) with an accuracy of $0.1 \mathrm{~g}$. The relative humidity of the seeds was determined using a moisture meter (LDS-1F). On each elementary plot, the average grain yield was calculated using the formula of Valdés et al. (2013):

$$
R=\frac{P \times 10000}{S I \times 1000} \times \frac{14 \%}{H}
$$

where $R$ is the average yield of maize, expressed in $\mathrm{t} / \mathrm{ha}$; $P$ is the fresh weight of maize per elementary computing area, expressed in $\mathrm{kg} S I$ is the surface interpretable expressed in $\mathrm{m}^{2} ; H$ is the moisture of the grains, expressed in percentage (\%); 100000 represents the conversion of ha in $\mathrm{m}^{2}$, and 1000 represents the conversion of ton $(\mathrm{t})$ in $\mathrm{kg}$.

\section{Chemical analysis of the soil at the experimental site}

The composite soil samples obtained prior to the implementation of the trial were analyzed at the Laboratory 
Table 2. Chemical characteristics of the soil at the experimental site

\begin{tabular}{ccccccccc}
\hline \multirow{2}{*}{$\begin{array}{c}\text { Depth } \\
{[\mathrm{cm}]}\end{array}$} & $\begin{array}{c}\mathrm{pH} \\
{[\text { water }]}\end{array}$ & $\begin{array}{c}\text { C-org } \\
{[\mathrm{g} / \mathrm{kg}]}\end{array}$ & $\begin{array}{c}\text { N-total } \\
{[\mathrm{g} / \mathrm{kg}]}\end{array}$ & $\begin{array}{c}\mathrm{P} \\
{[\mathrm{mg} / \mathrm{kg}]}\end{array}$ & \multicolumn{3}{c}{$\begin{array}{c}\text { Exchangeable bases } \\
{[\mathrm{cmol} / \mathrm{kg}]}\end{array}$} \\
\hline $0-20$ & 7.80 & 8.0 & 0.60 & 47.50 & 3.32 & 2.31 & 2.21 \\
\hline
\end{tabular}
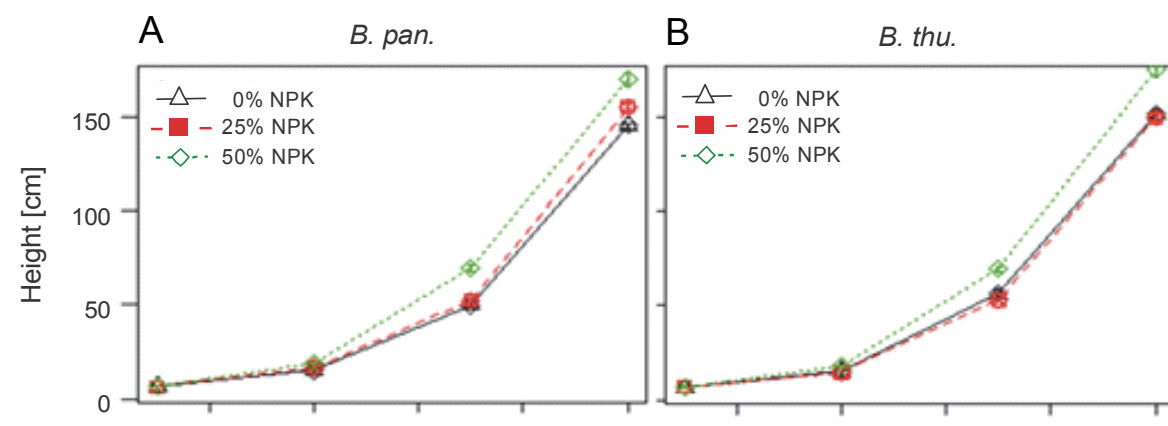

C B. pan., P. put., S. mar.

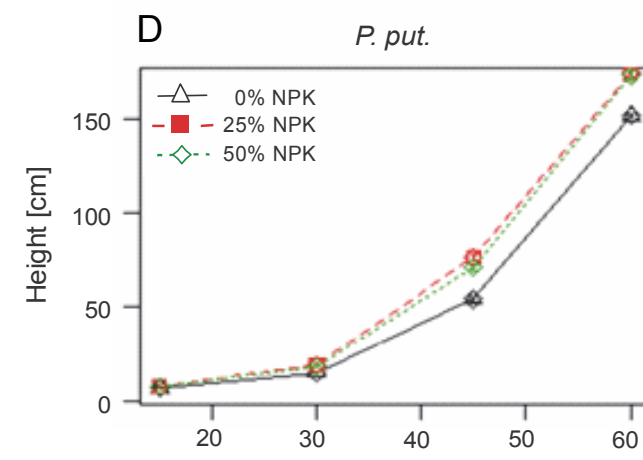

Day after seedling
E

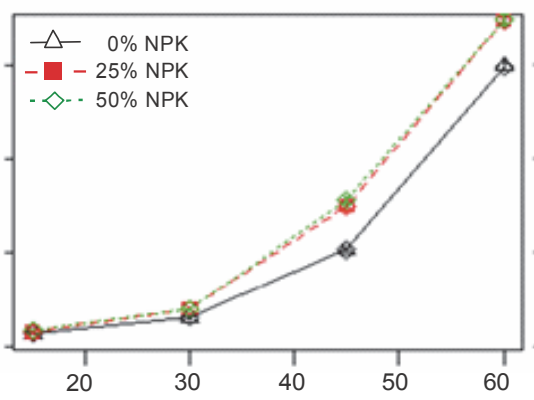

Day after seedling

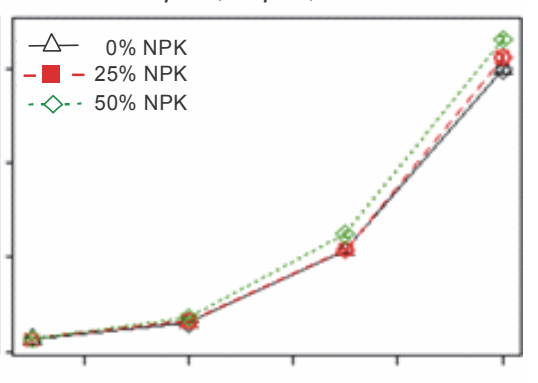

$\mathrm{F}$

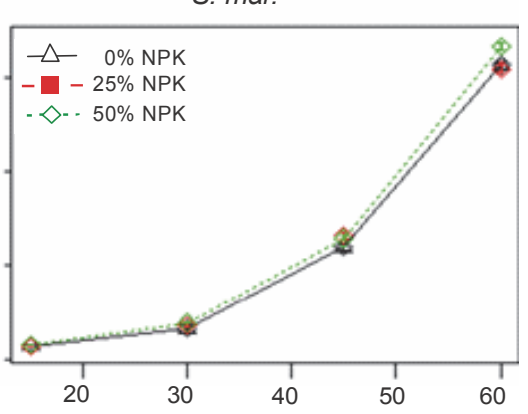

Day after seedling

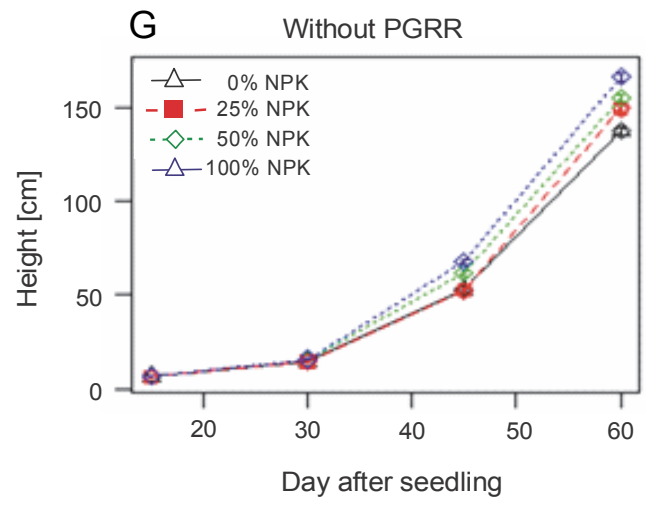

Fig. 2. Trend in the height of maize plants following the treatment with PGPR strains, NPK + urea dose, and combination of PGPR strains and various NPK + urea doses

of Soil, Water and Environment Sciences (LSSEE) of the National Institute of Agricultural Research in Benin (INRAB). These analyses included pH (Kumar et al., 2012), organic carbon (Lo etal., 2011), assimilable phosphorus (Olsen et Sommer, 1982), nitrogen (Bremner, 1996), potassium (Knudsen et al., 1982), and cation (Thomas, 1982).

\section{Statistical analysis}

For growth parameters such as height and collar diameter, a mixed linear model on longitudinal data was considered with the blocks constituting the random factor and the treatments, the fixed factor. The empty model with no factor was tested before choosing the unconditional growth model and the full conditional growth 

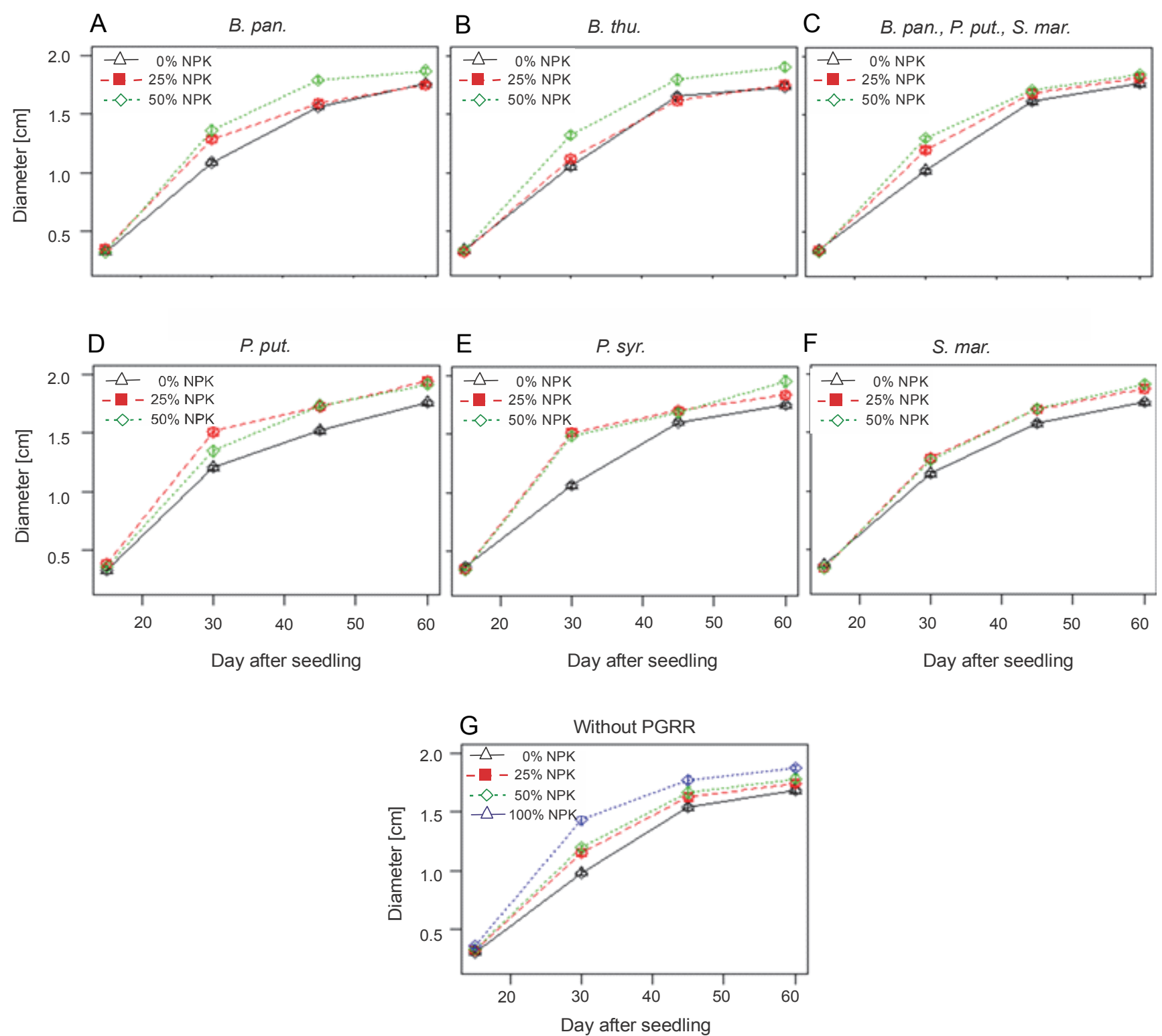

Fig. 3. The trend in diameters of maize plants according to the treatment type: PGPR strains, NPK + urea dose, and combination of PGPR strains and NPK + urea doses

model. By using this model, a simple analysis of variance (ANOVA) allowed to conclude on the significance of the PGPR and NPK dose factors, the time factor (day after sowing), and their interactions. Growth curves were constructed from the adjusted averages of the treatment factor levels to illustrate the dynamics of the plant growth under different treatments.

The effect of PGPR and NPK rates on the leaf area and other plant yield parameters was evaluated for each parameter by using ANOVA. Prior to ANOVA, normality and homoscedasticity of the data were verified using the Ryan-Joiner and Levene tests, respectively (Glèlè Kakaï et al., 2006). Post-hoc or multiple comparison tests (SNK test) of PGPR and NPK doses were performed, and error bars were constructed.

An ascending hierarchical classification with the UPGMA method in the "phangorn" package was performed to identify treatment groups based on the measured parameters. The different classes obtained were described to establish the specific characteristics of each group formed. In addition, a principal component analysis (PCA) was performed to identify the relationships between these parameters and the treatments, and between the treatments and the groups by using the 


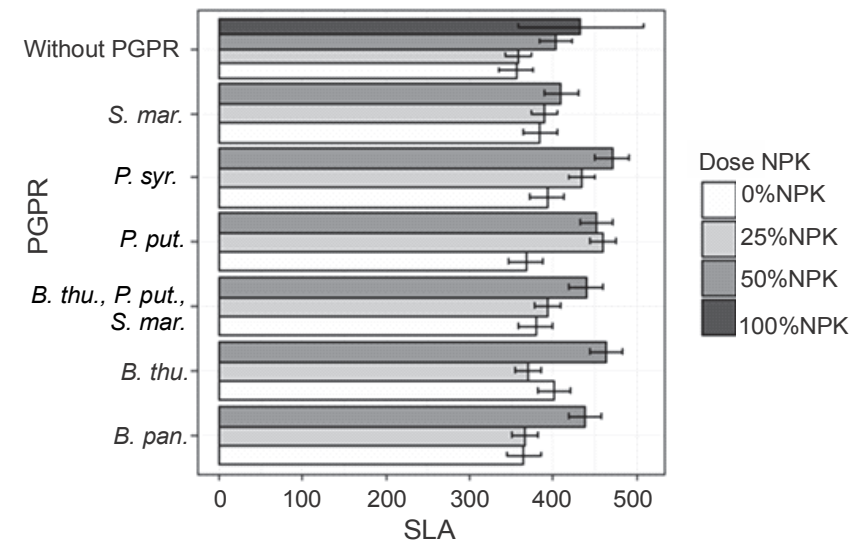

Fig. 4. Combined effects of PGPR and NPK rates on plant leaf areas

"FactoMineR," "factoextra," "corrplot," and "ggplot2" packages. This procedure was adopted for both PGPR and the combination of PGPR and NPK doses. The analyses were performed in $\mathrm{R}$ version 3.6.1 software ( $\mathrm{R}$ Core Team, 2019).

\section{Results}

\section{Soil chemistry of the study site}

Table 2 shows the chemical properties of the soil sampled at a depth of $20 \mathrm{~cm}$ at the experimental site. The contents of nitrogen $(0.6 \mathrm{~g} / \mathrm{kg})$, phosphorus $(47.5 \mathrm{mg} / \mathrm{kg})$, and carbon $(8 \mathrm{~g} / \mathrm{kg})$ in the study environment were at average levels and adequate for maize cultivation. The recorded $\mathrm{pH}$ value (7.8) indicated that the soil in the study environment was slightly alkaline. The sum of exchangeable bases $(7.84 \mathrm{cmol} / \mathrm{kg})$ obtained was also at the mean level in the study site.

\section{Effects of PGPRs on maize plant growth parameters}

\section{Changes in height of maize plants over time}

The best height $(166.06 \pm 14.75 \mathrm{~cm})$ was obtained for plants fertilized with the recommended dose (100\% NPK + urea) (Fig. 2). The ANOVA results indicated a very significant effect $(P<0.001)$ of fertilization on the height of corn plants. In addition, the combination of PGPR strains and NPK + urea dose $(P<0.05)$ significantly stimulated the plant height. The most effective treatments were $P$. put. $+25 \% \mathrm{NPK}+$ urea and $P$. syr. $+50 \%$ NPK + urea, followed by B. thu. + 50\% NPK + urea. These treatments enhanced the plant height to reach $174.17 \pm 11.82 \mathrm{~cm}, 174.25 \pm 15.01 \mathrm{~cm}$, and
$174.78 \pm 21.06 \mathrm{~cm}$, respectively, as compared to $137.39 \pm 14.44 \mathrm{~cm}$ for the control plants (which received neither PGPR nor NPK).

\section{Changes in diameter of maize plants over time}

According to the results of the linear mixed-effects model, the application of the different NPK doses without inoculation with PGPRs induced a significant effect $(P<0.0001)$ on plant crown diameter over time. The curves in Figure $3 \mathrm{G}$ indicate that the mean values of the largest collar diameters were recorded with the $100 \%$ $\mathrm{NPK}+$ urea treatments $(1.87 \pm 0.13 \mathrm{~cm})$, with an increase of $11.30 \%$ compared to that for the control plants. However, the combined effect of PGPR strains and NPK doses on plant crown diameter was not significant $(P>0.05)$ (Fig. 3). There was a slight increase in the mean diameter in the control and fertilized plants only. Indeed, the diameters of maize plants under the influence of B. pan. $+50 \% \mathrm{NPK}+$ urea, B. thu. $+50 \% \mathrm{NPK}+$ urea, P. put. $+50 \% \mathrm{NPK}+$ urea, $P$. syr. $+50 \% \mathrm{NPK}+$ urea, and S. mar. + 50\% NPK + urea reached $1.87 \pm 0.15 \mathrm{~cm}, 1.91$ $\pm 0.22 \mathrm{~cm}, 1.92 \pm 0.24 \mathrm{~cm}, 1.95 \pm 0.32 \mathrm{~cm}$, and 1.91 $\pm 0.22 \mathrm{~cm}$, respectively, as compared to $1.68 \pm 0.11 \mathrm{~cm}$ for the control plants.

\section{Leaf areas of plants}

At 60 DAS, the inoculation treatment with PGPR at various NPK doses induced a very high significant + difference in the plant leaf area compared to the uninoculated controls $(P<0.001)$ (Fig. 4). Indeed, all leaf area values recorded exceeded those of the control plants (Fig. 4). The highest leaf area values were observed in plants treated with $P$. syr. $+50 \%$ NPK $\left(470.43 \mathrm{~cm}^{2}\right)$, followed by P. put. $+50 \%$ NPK $\left(466.38 \mathrm{~cm}^{2}\right)$. Both treatments improved the leaf area up to 32.23 and $31.20 \%$, respectively, as compared to that for the controls.

Combined effects of PGPR and mineral fertilizer doses on the aboveground and belowground plant biomass and their ratios

Fresh aerial and underground biomasses and their ratio

The obtained results showed that PGPR inoculation induced better plant development. Indeed, the highest significant value $(P<0.05)$ of the aboveground fresh biomass was recorded for inoculation with $P$. syr. (1077.2 g), i.e., an improvement of $67.76 \%$ as compared 


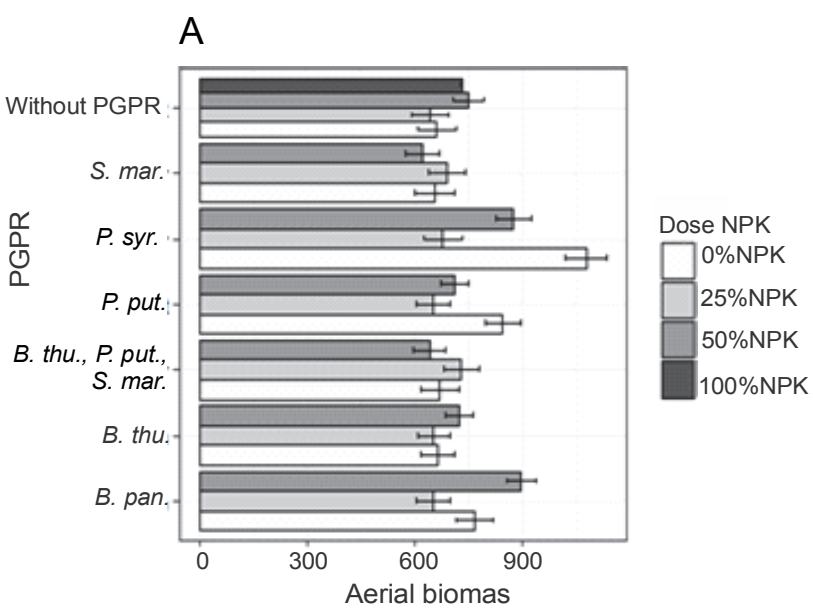

C

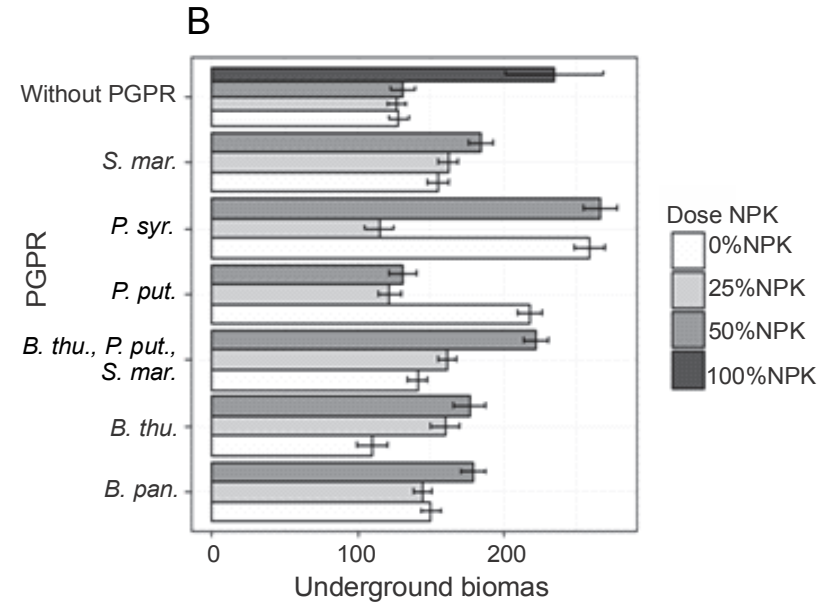

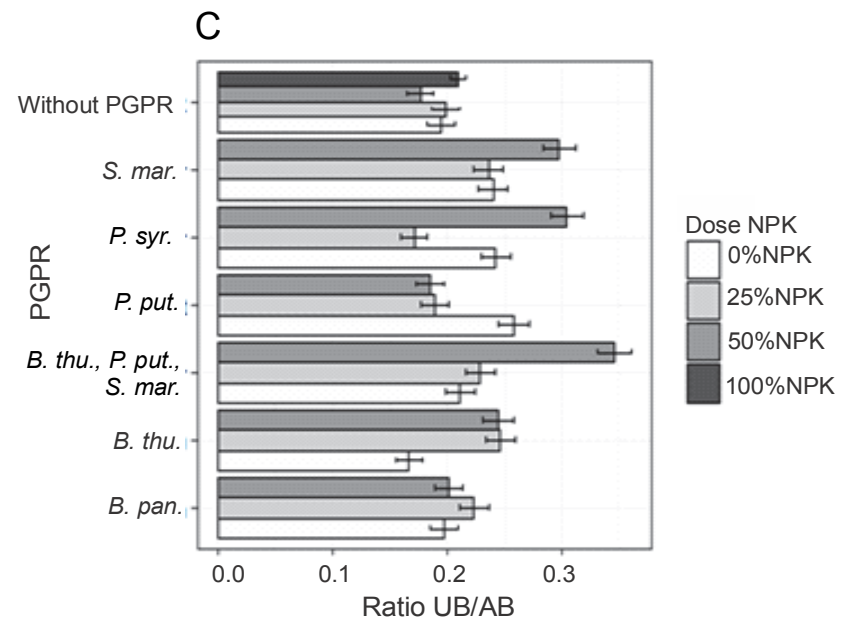

Fig. 5. Effects of PGPRs and their combination with different doses of NPK on the fresh weight of corn plant biomasses and their ratios

to that of the control plants (Fig. 5A). Two other treatments, namely B. pan. $+50 \% \mathrm{NPK}+$ urea $(896.53 \mathrm{~g})$ and P. syr. $+50 \% \mathrm{NPK}+$ urea $(874.61 \mathrm{~g})$, also stimulated this parameter significantly by 36.21 to $39.62 \%$ as compared to that for the controls (Fig. 5A). The lowest fresh aerial biomass was produced by plants inoculated with $S$. mar. Regarding the fresh underground biomass (Fig. 5B), the two best treatments were P. syr. $+50 \%$ NPK + urea and $P$. syr., which induced an improvement of 109.62 and $103.79 \%$, respectively, compared to that for the controls. Furthermore, the beneficial effect induced by the intake of $100 \%$ NPK + urea $(86.57 \%)$ revealed that the application of $P$. syr. in the presence of a reduced dose of NPK further stimulated the development of the root system of maize plants. The statistical analysis indicated a very highly significant $(P<0.001)$ influence of inoculation on the fresh underground biomass of the plants. The values of the fresh biomass ratio (Fig. $5 \mathrm{C}$ ) recorded with the treatments $B$. thu.,
P. put., S. mar. $+50 \%$ NPK + urea (84.21\%), $100 \%$ NPK + urea $(63.15 \%)$, and $P$. syr. $+50 \% \mathrm{NPK}+$ urea $(57.89 \%)$ showed that the inoculation of PGPR strains with reduced dose of mineral fertilizer was beneficial for the development of maize plants. Factors of interest (NPK dose and PGPR) and their interaction positively influenced the ratio of fresh plant biomass $(P<0.005)$.

\section{Dry aerial and underground maize biomasses and their ratios}

Among the treatments evaluated, two treatments, P. syr. $+25 \% \mathrm{NPK}+$ urea and P. syr. $+50 \% \mathrm{NPK}+$ urea, proved to be effective because of their beneficial effect on dry aerial maize biomass. In fact, the dry weights of the underground biomass of the plants were 581.4 $\pm 36.09 \mathrm{~g}$ and $451.7 \pm 10.83 \mathrm{~g}$ with the application of $P$. syr. $+25 \% \mathrm{NPK}+$ urea and P. syr. $+50 \% \mathrm{NPK}+$ urea, respectively, as compared to $298.9 \pm 13.43$ g recorded for the control plants (Fig. 6A). In addition, the effect of P. syr. $+25 \% \mathrm{NPK}+$ urea treatment on the dry weight of 

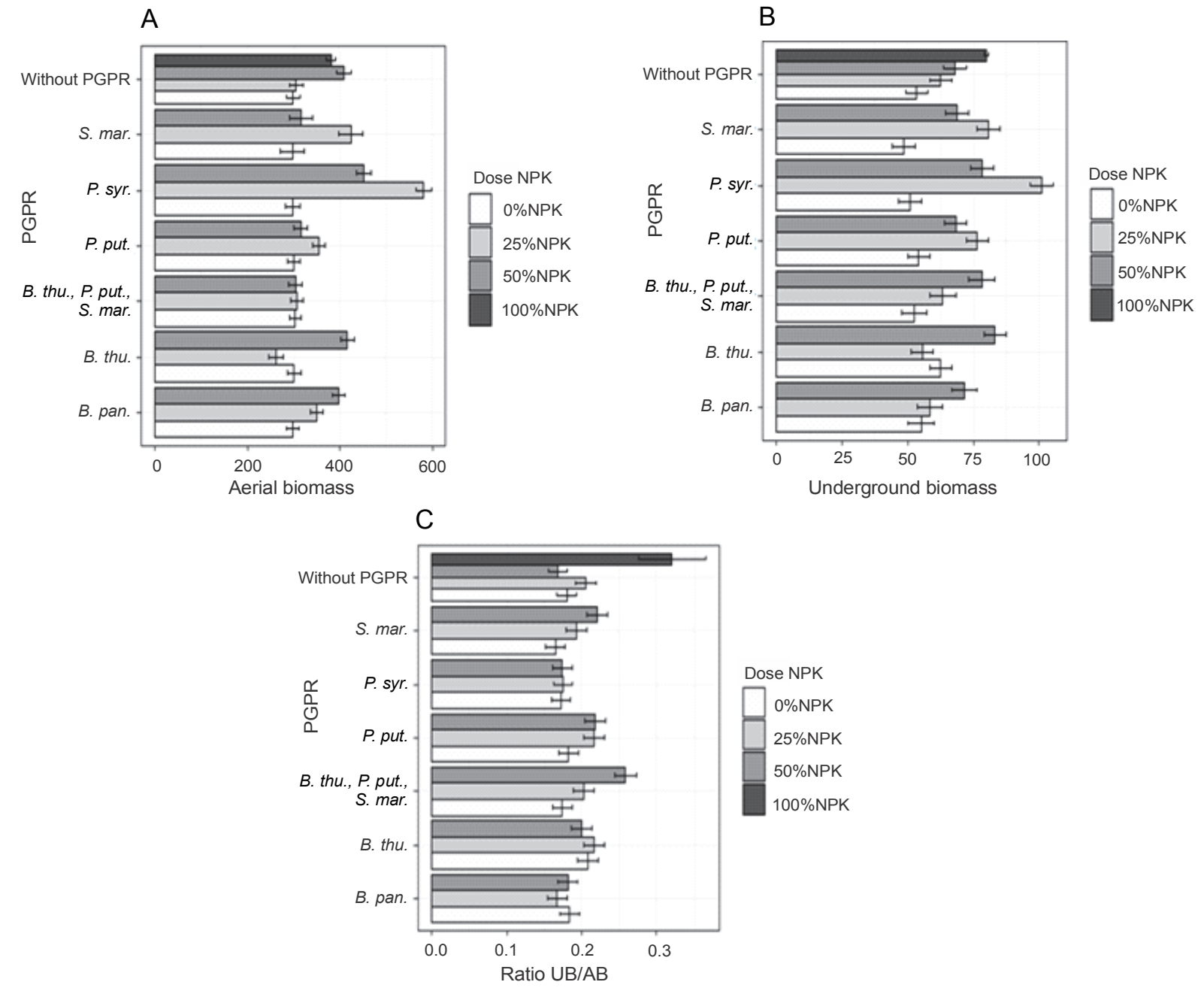

Fig. 6. Effects of PGPRs and the combination of different doses of NPK on the dry weights of the aboveground biomass of maize plants and their ratios

the underground biomass of the plants was also better. The results (Fig. 6B) showed that the greatest production of dry underground biomass was obtained with this treatment, i.e., an improvement of $89.09 \%$ more than that for the control plants. The ANOVA results indicated that the combination of PGPR and mineral fertilizer dose had a highly significant effect on biomass dry weight $(P<0.001)$. Similarly, the effects of the PGPR factor and the combination of PGPR and NPK dose were significant on the ratio of plant dry biomass. The highest ratio was obtained when the full dose $(100 \%$ NPK + urea) was used to fertilize the plants.

\section{Effects of PGPRs and the combination of different NPK doses on maize grain yield}

Figure 7 shows the effect of PGPR inoculation based on mineral fertilizer doses on grain yield. The best yields were recorded with the treatments $P$. syr. $+25 \%$ NPK
+ urea, $P$. syr. $+50 \%$ NPK + urea, and $P$. put. $+25 \%$ NPK + urea. However, no significant difference was observed between the effects induced by these treatments. Their applications increased the yields by 30.64 to $32.25 \%$ as compared to that of the control plants. For the plants fertilized with $100 \%$ NPK + urea, a lower grain yield was recorded compared to that for plants inoculated with $P$. syringae and $P$. putida in the presence of reduced doses of NPK+ urea, with an improvement rate of $17.74 \%$ as compared to that for the controls. The ANOVA results showed a significantly positive influence $(P<0.001)$ of the combined application of PGPR strain inoculation and reduced NPK doses on grain yield.

Classification of treatments based on the performance of PGPR strains tested in the absence of NPK

Four groups of PGPRs emerged from the bottom-up hierarchical classification. These groups (G1, G2, G3, 


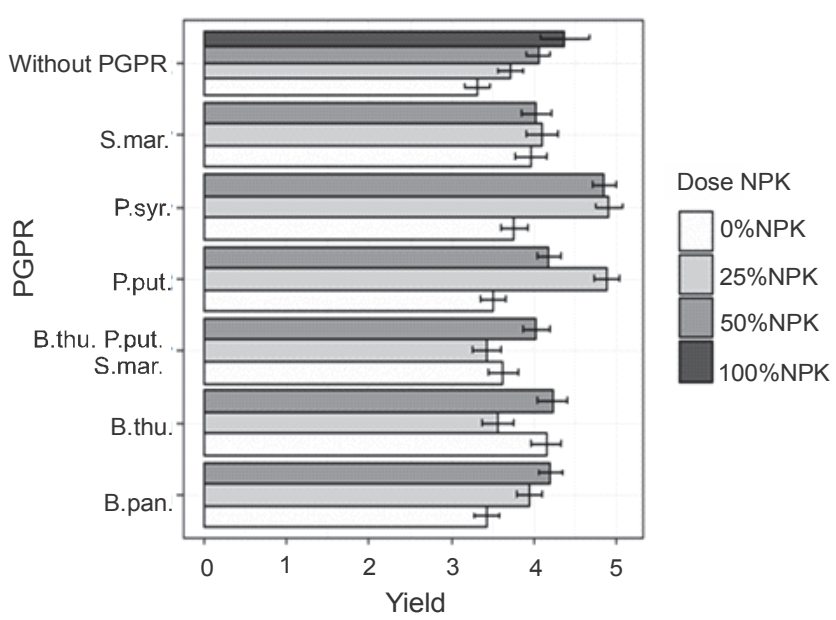

Fig. 7. Effect of PGPR inoculation and NPK doses on corn grain yield

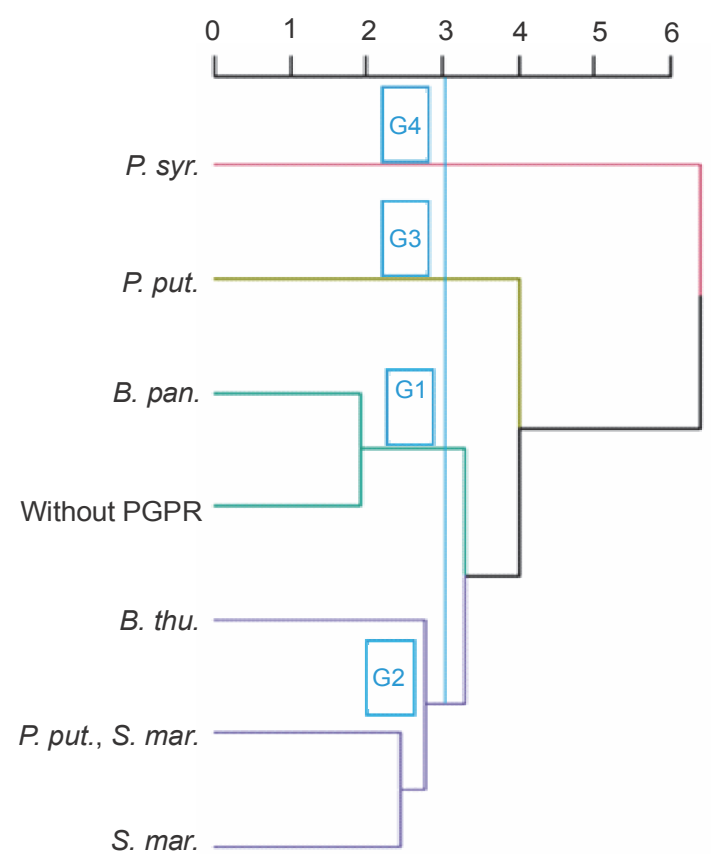

Fig. 8. Dendrogram showing hierarchical classification of treatments based on the performance of PGPR strains tested in the absence of NPK. B. thu. - Bacillus thuringiensis, B. pan. - Bacillus panthothenicus, $P$. put. - Pseudomonas putida, $P$. syr. - Pseudomonas syringae, S. mar. - Serratia marcescens

and G4) included 2 (B. pan. and without PGPR), 3 (S. mar., B. thu., P. put., B. thu.), 1 (P. put.), and 1 (P. syr.) treatments, respectively (Fig. 8). The results of ANOVA applied within the classes showed that these identified homogeneous groups were significantly different $(P<0.001)$ from each other in terms of the different parameters evaluated. Groups 3 and 4 showed the best performance for all the parameters tested.

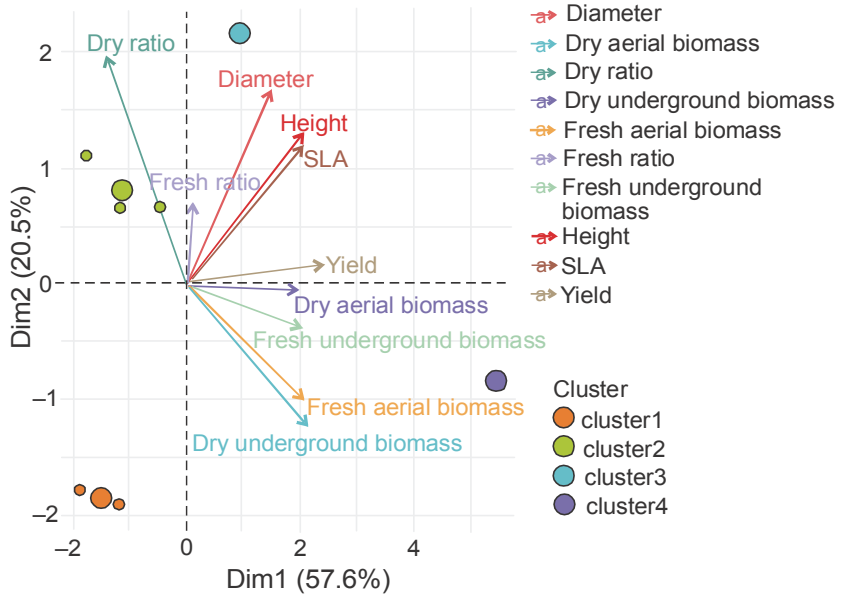

Fig. 9. Principal Component Analysis (PCA) of the relationship between height, diameter, leaf area (SLA), dry ratio, dry underground biomass, dry aerial biomass, fresh aerial biomass, yield, fresh ratio, and treatment groups G1 (cluster 1), G2 (cluster 2), G3 (cluster 3), G4 (cluster 4), and G5 (cluster 5) - PGPR inoculation without NPK fertilizer

A Main Component Analysis (CPA) was conducted to establish the correlation between the parameters assessed in the homogeneous groups and to identify the best treatments (Fig. 9). The results showed that all the parameters measured were positively correlated with axis 1 , except for the $U B / A B$ ratio. The latter was positively correlated with the second axis. Axis 1 therefore considers all the measured parameters. The projection of the groups and parameters on the first two axes (Fig. 9) confirmed the description of the classes obtained.

\section{Classification of maize treatments on the basis of the performance of PGPR strains combined with different doses of NPK}

The second level of classification considered all the treatments compared. The dendrogram showed that the treatments were divided into five homogeneous groups. These groups (G4, G3, G5, G2, and G1) included 1, 4, 1, 5 , and 11 treatments, respectively (Fig. 10).

The ANOVA results indicated the best performance of groups G2 (P. put. $+50 \%$ NPK + urea, P. put. $+25 \%$ $\mathrm{NPK}+$ urea, and $P$. syr. $+25 \% \mathrm{NPK}+$ urea $)$ and G5 $(P$. syr. $+50 \% \mathrm{NPK}+$ urea) on maize plant growth, biomass, and grain yield parameters. Figure 11 shows the correlation between the parameters evaluated within the groups. The analysis of this figure showed that parameters such as yield and biomass are correlated with axis 1 , while growth parameters are correlated with 


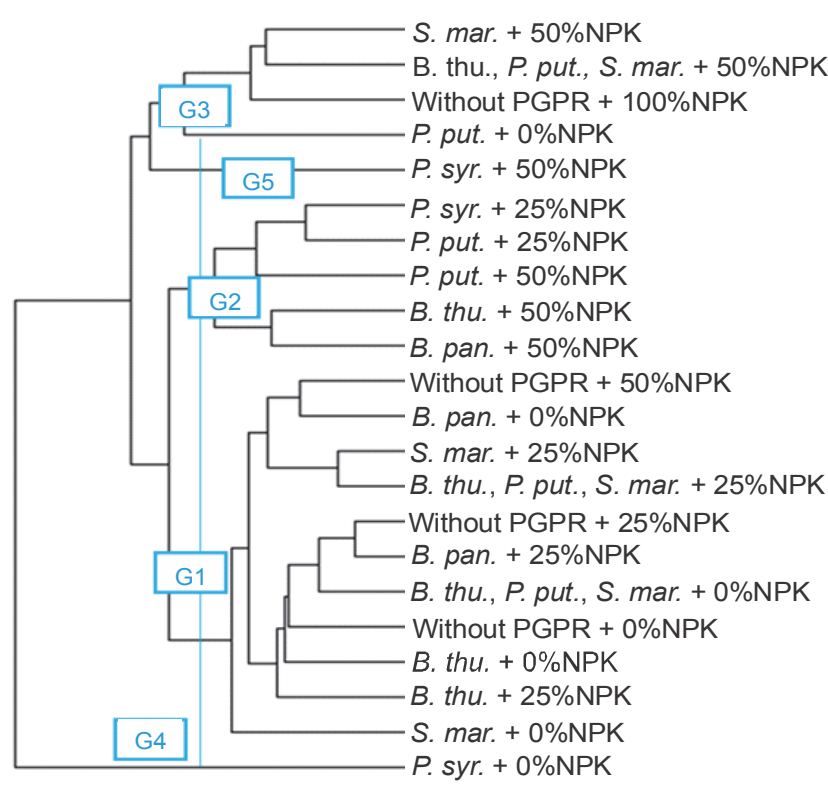

Fig. 10. Dendrogram showing hierarchical classification of treatments on the basis of the performance of PGPR strains combined with different doses of NPK. B. thu. - Bacillus thuringiensis, B. pan. - Bacillus panthothenicus, $P$. put. - Pseudomonas putida, P. syr. - Pseudomonas syringae, S. mar. - Serratia marcescens

axis 2. This projection of the groups and parameters on the first two axes allowed to select $P$. syr. $+50 \%$ NPK + urea as the most discriminating treatment.

\section{Discussion}

The use of PGPR strains in agricultural practices is strongly encouraged, as they can serve as a sustainable solution for improving the effectiveness of chemical fertilizers. The growth and development of different crops under various environmental conditions have been reported in response to PGPR inoculation with or without mineral fertilizers (Yao et al., 2006; Krey et al., 2013; Verma et al., 2013; Zahid et al., 2015; Pereira et al., 2020). In the present study, a positive effect of PGPR inoculation was noted on the height, diameter, biomass, and grain yield of maize plants with the intake of NPK mineral fertilizer. These results are similar to those reported by Saber et al. (2012) and Lavakush et al. (2014) who stated that the application of PGPRs as biological inoculants increases the growth and grain yield of cereals. In a recent study conducted in India, Zafar-ulHye et al. (2018) reported the efficacy of $P$. syringae $+50 \% \mathrm{NPK}+$ urea on maize plant height; an improvement of $63.63 \%$ and $119.5 \%$, respectively, was observed

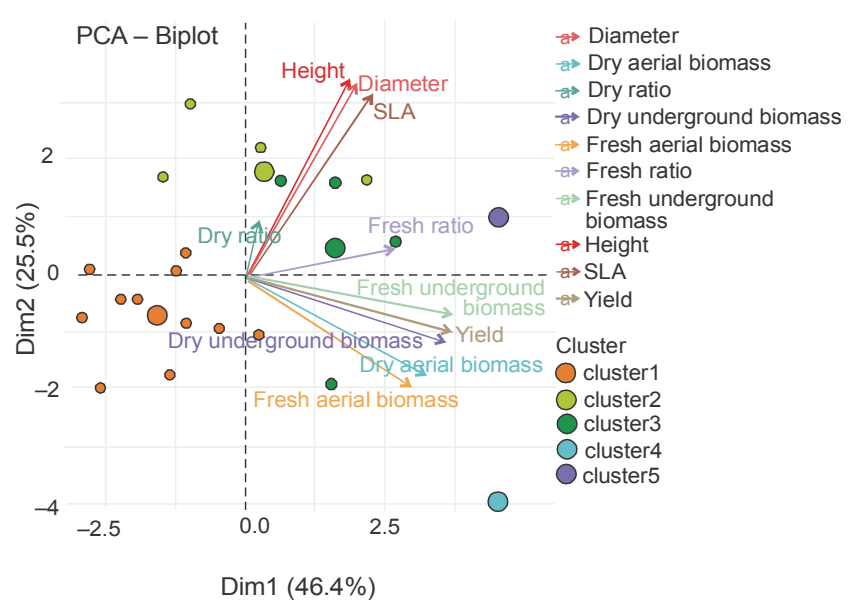

Fig. 11. Principal Component Analysis (PCA) of the relationship between height, diameter, leaf area (SLA), dry ratio, dry underground biomass, dry aerial biomass, fresh aerial biomass, yield, fresh ratio, and treatment groups G1 (cluster 1), G2 (cluster 2), G3 (cluster 3), G4 (cluster 4), and G5 (cluster 5) - PGPR inoculation combined with NPK fertilizer - from hierarchical classification

compared to the height of maize plants grown under the influence of recommended fertilizer application and control plants. In Northern Benin, the application of P. syr. $+50 \% \mathrm{NPK}+$ urea at the time of sowing maize of the 2000 SYNEE variety (an extra-precocious variety with a vegetative cycle of 80 days, a potential yield of $4 \mathrm{t} / \mathrm{ha}$ on the research station and $2.5 \mathrm{t} / \mathrm{ha}$ in the farming environment) showed positive results, resulting in again of $35.72 \%$ and $23.77 \%$ on the height and diameter, respectively, measured at the collar of maize plants (Amogou et al., 2019). In the present study, the height of plants under the effect of $P$. syr. $+50 \% \mathrm{NPK}+$ urea improved by $26.82 \%$ compared to that for the control plants. Although the response to inoculation with halfdose mineral fertilizer was highly variable, the effectiveness of $P$. syr. $+50 \% \mathrm{NPK}+$ urea was greater among all the treatments on the leaf surface when compared with the controls. On the other hand, the combined effect of inoculation and fertilization on the plant collar diameter was not significant. However, a slight improvement in the performance of $P$. syr. $+50 \% \mathrm{NPK}+$ urea was noted for this parameter $(4.27$ and $16.38 \%$ increase as compared to that for $100 \%$ NPK + urea application and controls, respectively).

The production of fresh aerial underground biomass was significantly improved compared not only to the control plants but also to fertilization in response to inoculation of maize plants by $P$. syringae. Indeed, with 
the application of $P$. syr. $+50 \% \mathrm{NPK}+$ urea and $P$. syr. alone, the root system of the plants was more improved (109.62 and $103.79 \%$, respectively) as compared to that for the controls. This performance exceeded the beneficial effect induced by the intake of $100 \% \mathrm{NPK}+$ urea (86.57\%), indicating that the use of this bacterial strain in the presence of a reduced dose of NPK would be more appropriate for sustainable maize production in central Benin. Our results corroborate those reported by Isfahani et al. (2012) who showed an improvement in root dry weight of treated cucumber as compared to that of controls, while the lowest dry weight was recorded in plants that received the full dose of $100 \%$ NPK mineral fertilizer (P100B0). Zafar-ul-Hye et al. (2015) reported that the application of $P$. syringae in the presence of $50 \%$ $\mathrm{NPK}+$ urea on maize seeds resulted in better improvement of fresh and dry underground biomass of the plants (55.54 and 57.83\%, respectively) as compared to those of unfertilized and uninoculated plants, respectively. According to these authors, the effectiveness of $P$. syringae could be explained by its ability to synthesize ACC deaminase, an enzyme known to be involved in reducing the harmful effects of ethylene produced by plants in response to saline stress. In addition, Ambrosini and Passaglia (2017) linked the promotion of plant growth to the ability of rhizobacteria to increase the activity of 1-aminocyclopropane-1-carboxylate deaminase. In terms of grain yield recorded in the present study, the best productivity was recorded with $P$. syr. $+25 \% \mathrm{NKP}+$ urea, $P$. syr. $+50 \% \mathrm{NPK}+$ urea, and $P$. put. $+25 \%$ NPK + urea. However, no significant difference was observed between the effects induced by these treatments. Their applications increased the yield by 30.64 to $32.25 \%$ as compared to that of the control plants. Our results were better than those reported by Amogou et al. (2019) who found $14.20 \%$ increase in the yield for maize seeds treated with $P$. syringae inoculation $+50 \% \mathrm{NPK}$ + urea. Moreover, these authors showed that $P$. put. $+50 \% \mathrm{NPK}+$ urea resulted in an increase in grain yield (35.5\%) as compared to that for the controls. These results are similar to those obtained with $P$. put. $+25 \%$ $\mathrm{NPK}+$ urea in our study. Although both these studies were conducted on the same type of soil (ferruginous soil), the difference in the performance of $P$. syr. $+50 \%$ $\mathrm{NPK}+$ urea might be related to the type of maize variety used. Lucy et al. (2004) showed that the effectiveness of PGPR strains varies considerably depending on the environmental conditions under study and that their ability to promote plant growth and development can be influenced by specific plant species, cultivars, soil type, and genotype. In another study on maize conducted by Sood et al. (2018), co-inoculation of a PGPR (B1N1) with $80 \%$ of the recommended rate of NP mineral fertilizer significantly increased maize grain yield by $11.7 \%$ as compared to that achieved after the application of the full recommended rate of mineral fertilizer $(100 \% \mathrm{NP})$. A $50 \%$ reduction in the use of NPK fertilizers and an improvement in grain yield of maize and barley have also been reported in other studies (Mehrvarz et al., 2008; Yazdani et al., 2009). The mechanisms by which the investigated PGPR strains promote plant growth were not evaluated in our study. Despite the reduction in the dose of mineral fertilizer, the good increase in all growth and yield parameters of plants inoculated with $P$. syr. $+50 \%$ NPK + urea can be explained by several factors. The $P$. syringae strain is among those reported PGPR isolates with multiple attributes that can significantly influence crop growth and yield (Abgodjato et al., 2018). PGPRs can promote plant growth by using their own metabolic activities (phosphate solubilization, hormone production, or nitrogen xation), by directly a ecting plant metabolism (increased water and mineral uptake), by improving root development, by increasing plant enzymatic activity, by "helping" other bene cial microorganisms to enhance their effect on plants, or by suppressing plant pathogens (Mantelin and Touraine, 2004; Pérez-Montaño et al., 2014). Several researchers (Bashan et al., 2004; Labidi et al., 2016) have explained the positive effect of PGPRs on the basis of their ability to produce auxins, represented primarily by indole acetic acid (IAA). The latter promotes greater capacity to absorb nutrients (Cassán and Diaz-Zorita, 2016) and the accumulation of reserves, which increases the diameter of the stems (Dartora et al., 2013), thus contributing to greater plant development. Fancelli and Dourado Neto (2000) reported that the larger the diameter of maize plants, the better these plants are able to resist the increasingly difficult environmental conditions, which contributes to a greater accumulation of organic solutes in the plants. This leads to better grain filling and therefore higher yields (Kappes et al., 2011). 


\section{Conclusion}

The results of the present study confirmed the efficacy of PGPR inoculation in combination with reduced rates of mineral fertilizer on maize growth and yield parameters. In the presence of $50 \%$ of the recommended dose of mineral fertilizer, the inoculation of $P$. syringae resulted in best improvements in height, leaf area, biomass, and grain yield of maize. Thus PGPR should be evaluated in large field trials to assess their potential for use as biofertilizers.

\section{Acknowledgements}

The authors sincerely acknowledge the funding obtained from the International Foundation for Sciences (IFS) (C/5252-2) and thank the National Centre for Specialization on Corn (CNS-Maïs). The authors also thank the "Fond National pour la Recherche Scientifique et l'Innovation Technologique (FRNSIT)" for their financial support.

\section{References}

Adjanohoun A., Noumavo P.A., Sikirou R., Allagbé M., Gotoechan-Hodonou H., Dossa K.K., Yèhouénou B., Glèlè Kakaï R., Baba-Moussa L. (2012) Effets des rhizobactéries PGPR sur le rendement et les teneurs en macroéléments du maïs sur sol ferrallitique non dégradé au Sud-Bénin. Int. J. Biol. Chem Sci. 6(1): 279-288.

Agbodjato N.A., Amogou O., Noumavo P.A., Dagbénonbakin G., Hafiz A.S., Kamirou R., Alladé A.M, Adebayo O., BabaMoussa F., Adjanohoun A., Baba-Moussa L. et al. (2018) Biofertilising, plant-stimulating and biocontrol potentials of isolated PGPR Rhizobacteria in central and northern Benin. Afr. J. Microbiol. Res. 12(28): 664-672.

Ahmad M., Adil1 Z., Hussain A., Mumtaz M.Z., Nafees M., Ahmad I., Jami M. (2019) Potential of phosphate solubilizing bacillus strains for improving growth and nutrient uptake in mungbean and maize crops. Pak. J. Agri. Sci. 56(2): 283-289.

Amadji G.L., Migan D.Z. (2001) Influence d'un amendement organique (compost) sur les propriétés physico-chimiques et la productivité d'un sol ferrugineux tropical. Ann. Sci. Agr. Bénin 2(2): 123-139.

Ambrosini A., Passaglia L.M.P. (2017) Plant growth-promoting bacteria (PGPB): isolation and screening of PGP activities. Curr. Prot. Plant Biol. 2: 190-209.

Amogou O., Dagbénonbakin G., Agbodjato N.A., Noumavo P.A., Salako K.V., Adoko M.Y., Kakaï R.G., Adjanohoun A., Baba-Moussa L. (2019) Applying rhizobacteria on maize cultivation in Northern Benin: effect on growth and yield. J. Agr. Sci. 10: 763-782.

Aparna Y., Sarada J. (2012) Molecular characterization and phylogenetic analysis of Serratia sp-YAJS: an extracellular dnase producer isolated from Rhi-zosphere soil. Sci. Res. Rep. 2(1): 104-109.
Azontondé A.H., Igué A.M., Dagbénonbakin G. (2010) Carte de fertilité des sols du Bénin par zone agroécologique du Bénin, Rapport Final, Benin.

Balogoun I. (2012) Essai de validation des formules d'engrais et des périodes de semis recommandées par le modèle DSSAT pour la production de maïs (Zea mays L.) au Sud et Centre Bénin. Mémoire de Diplôme d'Etude Approfondie, Faculté des Sciences Agronomiques, Université d'Abomey-Calavi, Bénin: 78.

Bashan Y., Holguin G., Bashan L.E. (2004) Azospirillum-plant relationships: physiological, molecular, agricultural, and environmental advances (1997-2003). Can. J. Microbiol. 55(8): 521-577.

Bremner J.M.: Nitrogen-Total. [in:] Methods of soil analysis. Part 3: Soil Science. Society of America, Madison (1996): 1085-1121.

Cassán F., Diaz-zorita M. (2016) Azospirillum sp. in current agriculture: form the laboratory to the field. Soil Biol. Biochem. 113(1): 117-130.

Dartora J., Guimarães V.F., Marini D., Sander G. (2013) Nitrogen fertilization associated with inoculation with Azospirillum brasilense and Herbaspirillum seropedicae in corn. Rev. Bras. Eng. Agr. Amb. 17(10): 284-297.

De Souza R., Ambrosini A., Passaglia L.M. (2015) Plant growth-promoting bacteria as inoculants in agricultural soils. Gen. Mol. Biol. 38(4): 401-419.

Dicko A.H., Babana A.H., Kassogué A., Fané R., Nantoum D., Ouattara D., Maiga K., Dao S. (2018) A Malian native plant growth promoting Actinomycetes based biofertilizer improves maize growth and yield. Springer Science + Business Media B.V.

Fancelli A.L., Dourado-Neto D. (2000) Corn production Guaiba, Agropecuária.

FAO (2009) How to feed the world in 2050. Insights from an expert meeting at FAO. 2050: 1-35.

Fox J., Weisberg S. (2019) An $R$ Companion to Applied Regression, $3^{\text {rd }}$ Edition. Thousand Oaks, CA http://tinyurl. com/carbook

Glèlè Kakaï R., Sodjinou E., Fonton H.N. (2006) Conditions d'application des méthodes statistiques paramétriques. Bibliothèque Nationale, Bénin.

Gogan A.C., Montcho P., Djivoh H., Houssou C. (2018) Programme national de développement de la filière maïs au Bénin (PNDF-Maïs 2018-2021). Bureau d'Analyses et d'Investigations (BAI); Bureau d'Etudes et d'Appui au secteur Agricole (B2A); Ministère de l'Agriculture de l'Elevage et de la Pêche (MAEP).

Gontia-Mishra I., Sapre S., Sharma A., Tiwari S. (2016) Amelioration of drought tolerance in wheat by the interaction of plant growth promoting rhizobacteria. Plant Biol. 18(6): 992-1000.

Govindappa M., Ravishankar R.V., Lokesh S. (2011) Screening of Pseudomonas fluorescens isolates for biological control of Macrophomina phaseolina root-rot of safflower. Afr. J. Microbiol. Res. 6: 6256-6266. 
Goyal A., Manoharachary C. (2014) Future challenges in crop protection against fungal pathogens. Springer New York.

Guiraud J., Galzy P. (1994) Contrôle Microbiologique dans les Industries Agroalimentaires. Doin.

Gyaneshwar P., Kumar G.N., Parekh L.J. Poole P.S. (2002) Role of soil microorganisms in improving $P$ nutrition of plants. Plant Soil. 245: 83-93.

Isfahani F.M., Besharati H. (2012) Effect of biofertilizers on yield and yield components of cucumber. J. Biol. Earth Sci. 2: 83-92.

Kappes C., Andrade J.A.C., Arf O., Oliveira A.C., Arf M.V., Ferreira J.P. (2011) Performance of corn hybrids in different spatial arrangements of plants. Bragantia 70(2): 334-343.

Knudsen D., Peterson G.A., Pratt P. (1982) Lithium, sodium and potassium. [in:] Methods of soil analysis. Ed. Page A.L. American Society of Agronomy. Wisconsin. Madison: 225.

Krey T., Vassilev N., Baum C., Eichler-Löbermann B. (2013) Effects of long-term phosphorus application and plantgrowth promoting rhizobacteria on maize phosphorus nutrition under eld conditions. Eur. J. Soil Biol. 55:124-130.

Kumar V., Bharti A., Negi Y.K., Gusain O., Pandey P., Bisht G.S. (2012) Screening of actinomycetes from earthworm castings for their antimicrobial activity and industrial enzymes. Braz. J. Microbiol. 205-214.

Lavakush Yadav J., Verma J.P., Jaiswal D.K., Kumar A. (2014) Evaluation of PGPR and different concentration of phosphorus level on plant growth, yield and nutrient content of rice (Oryza sativa). Ecol. Eng. 62: 123-128.

Lo I., Tsang D., Yip T., Wang F., Zhang W.H. (2011) Influence of injection conditions on EDDS-flushing of metal-contaminated soil. J. Hazard Mater. 192: 667-675.

Lucy M., Reed E., Glick B.R. (2004) Applications of free living plant growth-promoting rhizobacteria. Antonie Van Leeuwenhoek 86: 1-25.

Macauley H., Ramadjita T. (2015) Cereal crops: rice, maize, millet, sorghum, wheat. Feeding Africa 36.

MAEP (2017) MAEP Plan Stratégique de Développement du Secteur Agricole (PSDSA) 2025 et Plan National d'Investissements Agricoles et de Sécurité Alimentaire et Nutritionnelle PNIASAN 2017-2021.

Mahanty T., Bhattacharjee T.M.S, Goswami M., Bhattacharyya P., Das B., Ghosh A., Tribedi P. (2017) Biofertilizers: a potential approach for sustainable agriculture development. Env. Sci. Pollut. Res. Int. 24: 3315-3335.

Maheshwari D.K. (2012) Bacteria in agrobiology: plant probiotics. Springer Science \&Business Media.

Mantelin S., Touraine B. (2004) Plant growth-promoting bacteria and nitrate availability: impacts on root development and nitrate uptake. J. Exp. Bot. 55: 27-34.

Mehrvarz S., Chaichi M.R., Alikhani H.A. (2008) Effects of phosphate solubilizing microorganisms and phosphorus chemical fertilizer on yield and yield components of Barely (Hordeum vulgare L.). Am.- Euras. J. Agric. Environ. Sci. 3: 822-828.

Naik K., Mishra S., Srichandan H., Singh P.K., Sarangi P.K. (2019) Plant growth promoting microbes: potential link to sustainable agriculture and environment. Biocatal. Agricult. Biotech. 21: 101326.

Olsen S.R., Sommers L.E. (1982) Phosphorus. [in:] Methods of Soil Analysis. Part 2: Chemical and Microbiological Properties. Ed. Page A.L., Miller R.H., Keeney D.R. Agronomy, vol. 9. Madison, Wisconsin: 403-427.

Patra A.K., Le Roux X., Grayston S.J., Loiseau P., Louault F. (2008) Unraveling the effects of management regime and plant species on soil organic carbon and microbial phospholipid fatty acid profiles in grassland soils. Biores. Tech. 99: 3545-3551.

Pereira N.C.M., Galindo F.S., Gazola R.P.D., Dupas E., Rosa P.A.L., Mortinho E.S., Teixeira Filho M.C.M. (2020) Corn yield and phosphorus use efficiency response to phosphorus rates associated with plant growth promoting bacteria. Front. Environ. Sci. 8: 40.

Pérez-Montaño F., Alías-Villegas C., Bellogín R.A., del Cerro P., Espuny M.R., Jiménez-Guerrero I., López-Baena F.J., Ollero F.J., Cubo T. (2014) Plant growth promotion in ceral and leguminous agricultural important plants: from microorganism capacities to crop production. Microbiol. Res. 169: 325-336.

Rashid M.I., Mujawar L.H., Shahzad T., Almeelbi T., Ismail I.M., Oves M. (2016) Bacteria and fungi can contribute to nutrients bioavailability and aggregate formation in degraded soils. Microbiol. Res. 183: 62.

RugetF., BonhommeR., Chartier M. (1996) Estimation simple de la surface foliaire de plantes de maïs en croissance. Agronomie 16: 553-562.

Saber Z., Pirdashti H., Esmaeili M., Abbasian A., Heidarzadeh A. (2012) Response of wheat growth parameters to co-inoculation of plant growth promoting rhizobacteria (PGPR) and different levels of inorganic nitrogen and phosphorus. World Appl. Sci. J. 16(2): 213-219.

Saikia J., Sarma R.K., Dhandia R., Yadav A., Bharali R., Gupta V.K., Saikia R. (2018) Alleviation of drought stress in pulse crops with ACC deaminase producing rhizobacteria iso-lated from acidic soil of Northeast India. Sci. Rep. 8: 35-60.

Sikirou R., Boukari S., Idrissou-Toure M., Dossoumou A.M.E., Zocli B., Aboudou M., Idrissou B.S., Yo T., Adanguidi (2019) Manuel technique de protection du maïs en culture et en stockage au Bénin. Bibliothèque FAO; LDC/CRAAgonkanmey/INRAB/MAEP.

Sood G., Kaushal R., Chauhan A., Gupta S. (2018) Effect of conjoint application of indigenous $P G P R$ and chemical fertilizers on productivity of maize (Zea mays L.) under mid hills of Himachal Pradesh. J. Plant Nutr. Vol. 41(3): 297-303.

Tabassum B., Khan A., Tariq M., Ramzan M., Khan M.S.I, Shahid N., Aaliya K. (2017) Bottlenecks in commercialisation and future prospects of PGPR. Appl. Soil Ecol. 121: 102-117.

Thomas G.W. (1982) Exchangeable cation. [in:] Methods of soil analyse. Ed. Page A.L., Miller R.H., Keeney D.R. Madison: $154-157$.

Toléba Séidou M., Biaou G., Saïdou A., Zannou A. (2015) Fonctionnement de la filière maïs au Bénin. Cahiers du CBRST, Cotonou (Bénin) 73(1): 35-73. 
Valdés E.M.F., González E.C., Serrano M.M., Labrada H.R., Báez E.M., Hernández F.G., Hernández F.A. (2013) $E_{X^{-}}$ periencias obtenidas en el desarrollo participativo de hibridos lineales simples de maíz en condiciónes de bajos insumos agrícolas. Cult. Trop. 34(2): 61-69.

Verma J.P., Yadav J., Tiwari K.N. (2012) Enhancement of nodulation and yield of chickpea by co-inoculation of indigenous Mesorhizobium spp. and plant growth-promoting rhizobacteria in eastern Uttar Pradesh. Commun. Soil Sci. Plant Anal. 43: 605-621.

Wahyudi A.T., Astuti R.P., Widyawati A., Meryandini A., Nawangsih A.A. (2011) Characterization of Bacillus sp. strains isolated from rhizosphere of soybean plants for their use as potential plant growth for promoting Rhizobacteria. J. Microbiol. Antimicrob. 3: 34-40.

Yao A.V., Bochow H., Karimov S., Boturov U., Sanginboy S., Sharipov A.K. (2006) Effect of FZB24® Bacillus subtilis as a biofertilizer on cotton yields in field tests. Arch. Phytopathol. Plant Prot. 39(4): 323-328.

Yallou C.G., Aïhou K., Adjanohoun A., Toukourou M., Sanni O.A., Ali D. (2010) Itinéraires techniques de production de maïs au Bénin. Fiche technique. Dépôt légal Nº 4922 du 3 Décembre, Bibliothèque Nationale du Bénin: 18.
Yazdani M., Bahmanyar M.A., Pirdashti H., Esmaili M.A. (2009) Effect of Phosphate solubilization microorganisms (PSM) and plant growth promoting rhizobacteria (PGPR) on yield and yield components of Corn (Zea mays L.). Proc. World Acad. Sci. Eng. Technol. 37: 90-92.

Zafar-ul-Hye M., Nasir A., Zahir Z.A., Rahim A. (2015) Rhizobacterial inoculation integrated with mineral fertilizers promote maize productivity in saline-sodic soil subjected to compactness. Pak. J. Agric. Agril. Eng. Vet. Sci. 30: 43-53.

Zafar-ul-Hye M., Nasir A., Aon M., Hussain S., Ahmad M., Naz I. (2018) Seed inoculation with Pseudomonas fluorescens and Pseudomonas syringae enhanced maize growth in a compacted saline-sodic soil. Fyton 87: 25-31.

Zahid M., Abbasi M.K., Hameed S., Rahim N. (2015) Isolation and identi cation of indigenous plant growth promoting rhizobacteria from Himalayan region of Kashmir and their effect on improving growth and nutrient contents of maize (Zea mays L.) Front. Microbiol. 6: 207.

Zahir Z.A., Ahmad M., Hilger T.H., Dar A., Malik S.R., Abbas G., Rasche F. (2018) Field evaluation of multistrain biofertilizer for improving the productivity of different mungbean genotypes. Soil Environ. 37: 45-52. 